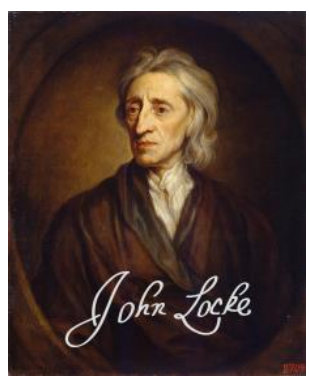

LOCKE STUDIES

Vol. 14

https://doi.org/10.5206/ls.2014.738 | ISSN: 1476-0290

Originally published: 2014

Published online: 19 FEBRUARY 2018

(C) Locke Studies, 2014

\title{
Review of La morale di Locke. Fra Prudenze e Mediocritas by Giuliana Di Biase
}

\author{
DIEGO LUCCI (AMERICAN UNIVERSITY IN BULGARIA)
}

Recommended citation:

Lucci, Diego. "Review of La morale di Locke. Fra Prudenze e Mediocritas by of Giuliana Di Biase." Locke Studies 14 (2014): 273-275. https://doi.org/10.5206/ls.2014.738

For more information about this article:

https://ojs.lib.uwo.ca/index.php/locke/article/view/738

Locke Studies is published by The John Locke Society.

This is an open access article published under the terms of the Creative Commons AttributionNonCommercial-ShareAlike 4.0 International license, which permits use, distribution and reproduction in any medium, provided the original work is properly cited and shared under the original license. 
Giuliana Di Biase, La morale di Locke. Fra Prudenza e Mediocritas. (Rome: Carocci, 2012. Pp. 325. Price €32.00. ISBN 978-8-84-306615-5).

Reviewed by DIEGO LUCCI

In this book, Giuliana Di Biase explores the meaning and significance of the concept of prudence in John Locke's thought. Di Biase argues that this concept played an important role not only in Locke's philosophy, but also in his life.

Her study of Locke's moral thought, and of his views on prudence in particular, is largely based on Locke's correspondence with several notable figures in English and European intellectual, cultural and political life-most prominently with the First Earl of Shaftesbury, the Irish patriot William Molyneux, the Whig political thinker James Tyrrell, the Quaker merchant Benjamin Furly, the Remonstrant theologian Philippus van Limborch, the freethinker Anthony Collins and the influential woman of letters Damaris Cudworth, later Masham. Besides Locke's letters, Di Biase takes into consideration the major published works of the 'father of liberalism', some of his unpublished manuscripts and his journals. She also concentrates on the major political events that impacted, in different ways, on Locke's life-from his youth to his exile in the Netherlands, and from his return to England after the Glorious Revolution to his later years, when he devoted most of his time and energy to biblical hermeneutics. Thus, Di Biase also provides the reader with a rich and compelling sketch of Locke's life and of the times in which he lived and wrote.

The book is divided into four chapters, which deal with the role of prudence in Locke's reflections on language, in his defences of toleration, in his political thought and in his moral philosophy. Di Biase clarifies that the term 'prudence', which Locke sometimes gave in Latin (prudentia), does not have a univocal meaning either in the history of western philosophy or 
even in Locke's works and letters. She demonstrates that Locke's prudence cannot be compared to the Aristotelian concept of 'phronesis' or 'practical wisdom', whose aim was to lead humankind to practice virtue. On the other hand, Locke's view of prudence differs from the meaning that this term acquired among later Scholastic philosophers, who construed it as one's ability to calculate the benefits one could gain from certain forms of conduct.

Locke recommended that his friends, especially the Reverend Richard King, read Cicero's De Officiis and the Bible, particularly Ecclesiasticus, when he attempted to clarify his conception of prudence. It is no accident that Locke made reference to a masterpiece of Stoic philosophy and to a religious text: as Di Biase points out, Locke drew on both Stoicism and Christian ethics in distinguishing prudence from both wisdom and virtue. Whereas he considered the practice of wisdom in personal choices to be essential to achieving happiness, and whereas he regarded the cultivation of virtue as critical to the development of morality, he judged prudence to be a complex disposition of the mind - a disposition that translates into a series of behaviors, such as one's ability to ponder one's words, and to keep silent when needed, and the capacity to avoid clashes, troubles and difficult situations. In other words, Locke's view of prudence is connected to his idea of mediocritas, that is, the ability to understand the limits of our knowledge, capabilities and action and never to trespass such limits. And Di Biase remarks that, according to Locke, human beings are not naturally disposed to acquire prudence and cannot learn it from everyday life, but they can appreciate and practice prudence thanks to the study of history, which Locke regarded as a very important factor in the education of good citizens and conscientious politicians. Moreover, Di Biase highlights that Locke's appreciation of prudence and mediocritas also characterized his attitude to religious issues, as can be seen in his advocacy of toleration (from his early essay on the subject to A Letter concerning Toleration), in his defence of 
freedom of conscience and in his attempt to demonstrate the reasonableness of Christianity.

In conclusion, the portrait of Locke that emerges from Giuliana Di Biase's detailed analysis of his works, correspondence and biography is not only - in the opinion of this reviewer-accurate, but also interesting and original. This book sheds new light on the public as well as personal life of the founder of modern empiricism, since it presents a revaluation of a concept (i.e. prudence) that played a significant role in Locke's political, moral and religious life and thought. For all these reasons, this book is a commendable piece of scholarship, which combines well with some of the best studies on Locke's political, moral and religious ideas, such as Ian Harris's, John Marshall's and Victor Nuovo's relatively recent studies. It deserves to be read by all those interested in the philosophy of the Enlightenment and in Locke's philosophy in particular.

American University in Bulgaria 